A.P. Kusyak ${ }^{1}$, A.L. Petranovska ${ }^{1}$, S.P. Turanska ${ }^{1}$, O.I. Oranska ${ }^{1}$, Yu.M. Shuba ${ }^{2}$, D.I. Kravchuk ${ }^{2}$, L.I. Kravchuk ${ }^{2}$, V.S. Chornyi ${ }^{3}$, O.A. Bur'yanov ${ }^{3}$, Yu.L. Sobolevs'kyy ${ }^{3}$, V.A. Dubok ${ }^{4}$, P.P. Gorbyk ${ }^{1}$

\title{
SYNTHESIS AND PROPERTIES OF NANOSTRUCTURES BASED ON LANTHANUM FLUORIDE FOR PHOTODYNAMIC THERAPY OF TUMORS OF THE CRANIAL CAVITY AND BONE TISSUE
}

\author{
${ }^{1}$ Chuiko Institute of Surface Chemistry of National Academy of Sciences of Ukraine \\ 17 General Naumov Str., Kyiv, 03164, Ukraine, E-mail: phorbyk@ukr.net \\ ${ }^{2}$ Bogomolets Institute of Physiology of National Academy of Sciences of Ukraine \\ 4 Bogomoletz Str., Kyiv, 01601, Ukraine \\ ${ }^{3}$ Bogomolets National Medical University \\ 13 Taras Shevchenko Blvd., Kyiv, 02000, Ukraine \\ ${ }^{4}$ Frantsevich Institute of Problems of Materials Science of National Academy of Sciences of Ukraine \\ 3 Akademika Krzhyzhanovskoho Str., Kyiv, 03142, Ukraine
}

The aim of the work is the synthesis of nanostructures based on lanthanum fluoride, promising for use in photodynamic therapy of tumors in organs of cranial cavity and bone tissues; a study of their structural properties and luminescence spectra. Synthesis of $\mathrm{LaF}_{3}: \mathrm{Tb}^{3+}$ was carried out by coprecipitation of components from aqueous and alcoholic (methanol) solution. As precursors were used: $\mathrm{La}\left(\mathrm{NO}_{3}\right)_{3} \times 6 \mathrm{H}_{2} \mathrm{O}, \mathrm{TbCl}{ }_{3}, \mathrm{NH}_{4} \mathrm{~F}$. All reagents have qualification "chemically pure". Distilled water and methanol were used as solvent. The synthesis of nanosized magnetite in the single-domain state was performed by the Elmore method. Synthesized nanodisperse samples are characterized by XRD analysis, DTGA, TEM. The magnetic properties and spectra of UV luminescence were also studied. It has been found that the XRD-patterns of $\mathrm{LaF}_{3}: \mathrm{Tb}^{3+}$ samples synthesized in water and methanol do not differ fundamentally. Under the experimental conditions, the most perfect crystals of hexagonal syngony were formed during crystallization in an autoclave. Their average size was $\sim 15 \mathrm{~nm}$. In TEM images, the length of the crystals exceeds the width by 3-4 times. Crystals are prone to aggregation and the formation of chain structures. The UV luminescence spectrum of the synthesized nanodisperse samples in aqueous medium at the concentration of $0.5 \mathrm{mg} / \mathrm{ml}$ and excited by ultraviolet radiation is characteristic of the structure of $\mathrm{LaF}_{3}: \mathrm{Tb}^{3+}$. Ensembles of particles $\mathrm{Fe}_{3} \mathrm{O}_{4} / \mathrm{LaF}_{3}: \mathrm{Tb}^{3+} \mathrm{NCs}$ were synthesized. Transmission electron microscopy has shown that the shapes of particles of NCs and LaF $: T b^{3+}$ nanocrystals are fundamentally different. Particles of $\mathrm{Fe}_{3} \mathrm{O}_{4} / \mathrm{LaF}_{3}: \mathrm{Tb}^{3+} \mathrm{NCs}$ have a spherical shape, which is characteristic of structures of the core-shell type. X-ray diffraction patterns of NCs confirm this conclusion. The conditions for the synthesis of NCs did not significantly change the magnetic properties of their nuclei, single-domain $\mathrm{Fe}_{3} \mathrm{O}_{4}$ nanoparticles (NPs). The luminescence spectrum of $\mathrm{Fe}_{3} \mathrm{O}_{4} / \mathrm{LaF}_{3}: \mathrm{Tb}^{3+} \mathrm{NCs}$ differs significantly from the spectrum of samples of nanodispersed $\mathrm{LaF}_{3}: \mathrm{Tb}^{3+}$ both in intensity and in the structure of the bands. These spectral differences may be due to differences in structure, features of the nanocrystalline structure, the content of the LaF $F_{3}: T^{3+}$ scintillator and $\mathrm{Tb}^{3+}$ ions in samples of $\mathrm{LaF}_{3}: \mathrm{Tb}^{3+}$ nanocrystals and shells of $\mathrm{Fe}_{3} \mathrm{O}_{4} / \mathrm{LaF}_{3}: \mathrm{Tb}^{3+}$ nanocomposites. Composites of dispersed $60 \mathrm{~S}$ bioglass with nanodispersed crystalline $\mathrm{LaF}_{3}: \mathrm{Tb}^{3+}$ in the dry state, and distilled water, showed the presence of luminescence upon excitation by UV radiation. The results of research show the prospects of the synthesized nanodispersed luminophors $\mathrm{LaF}_{3}: \mathrm{Tb}^{3+}$, for use as a source of luminescent radiation in optopharmacology and photodynamic therapy of tumors in organs of cranial cavity and bone tissues. Optimization of luminescent properties of the original nanodispersed luminophors, their compositions with bioactive glass, luminescent shells in the composition of magnetosensitive NCs, as well as the technology of manufacturing of these structures will significantly allow us to improve their performance characteristics. The results of the work indicate the prospects of the synthesized structures for further research under the conditions of excitation by high-permeability "soft" $X$ ray radiation for use in optopharmacology and photodynamic therapy of tumors in organs of cranial cavity and bone tissues. Optimization of properties of the original nanodispersed luminophors, their compositions with bioactive glass and magnetosensitive carriers $\mathrm{Fe}_{3} \mathrm{O}_{4}$ will allow us to improve significantly their performance characteristics.

Keywords: nanodisperse luminophors, lanthanum fluoride, nanocomposites, magnetite, bioglass

(c) A.P. Kusyak, A.L. Petranovska, S.P. Turanska,

O.I. Oranska, Yu.M. Shuba, D.I. Kravchuk, L.I. Kravchuk,

V.S. Chornyi, O.A. Bur'yanov, Yu.L. Sobolevs'kyy,

V.A. Dubok, P.P. Gorbyk, 2021 


\section{INTRODUCTION}

The problem of creating multifunctional drugs for targeted delivery with dosed local release of bioactive components is relevant in many areas of modern medicine. Thus, for oncology, the development of the concept of chemical construction of magnetosensitive nanocomposites (NCs) of the core-shell type with a multilevel hierarchical layered shell nanoarchitecture capable of performing the functions of medical-biological nanorobots: recognition of specific cells, viruses and biomacromolecules in biological media; targeted delivery and deposit of drugs in cells and target organs; combined local chemo-, immuno-, neutron-capture-, hyperthermic-, photodynamic therapy and magnetic resonance imaging diagnostics in real time; detoxification of the body by adsorption of degradation residues of cells, viral particles, heavy metal ions, etc. and their removal by magnetic field is a priority [1-5].

In onco-orthopedic surgery, the development of new types of implants for use as a comprehensive delivery system for chemotherapeutic and osteoconductive drugs with prolonged action for topical use is a priority [6]. When using topical drug release, there are difficulties associated with the fixation and subsequent removal of the implant, which can cause additional stress on the body. From this point of view, bioactive ceramics, in particular different types of sol-gel glass, have an undeniable advantage over many other drug carriers because they are biocompatible, do not cause a negative immune response, are quickly and reliably fixed due to direct biochemical interaction with adjacent tissues, do not encapsulated with the formation of connective tissue (which is characteristic of foreign materials), as well as gradually biodegradable in the body by resorption and biochemical reactions [7-9]. A significant advantage of bioceramic materials is their capability to introduce into them the necessary substances in order to expand their functional properties and improve efficiency. In particular, in recent years, the efforts of researchers in this field are aimed at introducing a method of photodynamic therapy (PDT), which can be used for minimally invasive treatment of malignant tumors localized in soft tissues and in hard to reach places, such as organs of cranial cavities, bone structures, etc. [10].
It is known that PDT - a method of treatment based on the use of photosensitive substances, photosensitizers, is used in oncology, as well as in the treatment of certain skin diseases and infectious diseases [11-14]. Traditionally, the photosensitizer (PS) is administered intravenously, but can also be used by application or orally. PS for PDT selectively accumulates in the tumor or other pathologically affected target tissues or cells, after which they are irradiated with light with a wavelength corresponding to the maximum absorption of PS. Lasers that emit light of the desired wavelength and sufficient intensity are used as the light source. The uptake of light quanta by photosensitizer molecules in the presence of oxygen leads to a photochemical reaction, as a result of which molecular triplet oxygen is converted into singlet oxygen, and a large number of highly active radicals are formed. Singlet oxygen and radicals cause apoptosis and / or necrosis in tumor cells. In addition, PDT leads to the death of the tumor due to damage of its microvessels.

New approaches that may be useful for treatment, in particular minimally invasive, malignant tumors localized in the cranial organs, bone tissue, etc., may be photodynamic therapy and optopharmacology. These methods are based on the use of magnetically sensitive carriers for targeted delivery of drugs, modern bioceramic osteoconductive materials and highly efficient biocompatible nanosized luminophors with specified spectral characteristics of absorption and luminescence, safe for human body photosensitizers and high-permeable "soft" X-ray radiation [14-17].

At this time in the Chuiko Institute of Surface Chemistry of National Academy of Sciences of Ukraine there is developed and studied a wide class of nanosized magnetically sensitive materials: metal particles $\mathrm{Fe}, \mathrm{Co}, \mathrm{Ni}$, singledomain ferrites $\mathrm{Fe}_{3} \mathrm{O}_{4}, \quad \mathrm{MnFe}_{2} \mathrm{O}_{4}, \mathrm{NiFe}_{2} \mathrm{O}_{4}$, $\mathrm{CoFe}_{2} \mathrm{O}_{4}, \mathrm{GdFe}_{2} \mathrm{O}_{4}$, solid solutions in systems $\left(\mathrm{Fe}_{1-\mathrm{x}} \mathrm{Mn}_{\mathrm{x}}\right) \mathrm{Fe}_{2} \mathrm{O}_{4},\left(\mathrm{Fe}_{1-\mathrm{x}} \mathrm{Ni}_{\mathrm{x}}\right) \mathrm{Fe}_{2} \mathrm{O}_{4},\left(\mathrm{Fe}_{1-\mathrm{x}} \mathrm{Co}_{\mathrm{x}}\right) \mathrm{Fe}_{2} \mathrm{O}_{4}$, $\left.\left(\mathrm{Fe}_{1-\mathrm{x}} \mathrm{Zn}_{\mathrm{x}}\right) \mathrm{Fe}_{2} \mathrm{O}_{4}\right)$ [18] etc. By changing their type and varying the chemical composition, it is possible to meet many requirements that arise when creating NCs for biomedical, environmental and technical applications with a given set of properties. It should be noted that nanosized onedomain magnetite $\left(\mathrm{Fe}_{3} \mathrm{O}_{4}\right)$ has become especially widely used, in particular, for medical purposes [14]. It is known that magnetite has a biogenic 
nature, and its unique properties, methods of manufacture, surface modification, creation of magnetic fluids based on $\mathrm{Fe}_{3} \mathrm{O}_{4}$, are well studied. Therefore, magnetite has become one of the most promising materials for the manufacture of multifunctional drug carriers with optimal properties and NCs.

At the I.M. Frantsevich Institute of Problems of Materials Science of the National Academy of Sciences of Ukraine, a new generation of highly effective bioactive ceramics was created, the peculiarities of their properties were studied, and the results of clinical applications were analyzed at Bogomolets National Medical University $[19,20]$. Bioceramic materials have been used to develop new nanocomposites with antitumor drugs [6].

The list of photosensitizers that have been tested in clinical trials and are most widely known as photodynamic drugs includes: a derivative of benzoporphyrin - verteporfin; ethylthiopurpurin tin - purlitin; Lu-Tex - texaphyrin lutetium; hematoporphyrin derivatives and sodium porfimer (Photofrin), etc. [11]. In addition, at this time there are many organic compounds that are promising for use as photosensitizers, which are at the stage of laboratory research [14-17].

Based on the focus of the work on the synthesis and study of the properties of nanodispersed luminophors for photodynamic therapy of tumors of the cranial cavity and bone tissues, promising for research may be X-ray luminescent nanosized $\mathrm{LaF}_{3}$ particles doped with ions of rare earth elements, obtained by the technology of co-precipitation with aqueous solutions [15-17]. Their research, at least at the initial stage, in order to optimize the synthesis technology, it is advisable to conduct using ultraviolet (UV) radiation, which is much easier and safer to work with than X-ray.

Therefore, the aim of this work is the synthesis of nanostructures based on lanthanum fluoride, promising for use in photodynamic therapy of tumors in organs of cranial cavity and bone tissues; study of their structural properties and luminescence spectra.

\section{MATERIALS AND METHODS OF RESEARCH}

\section{Synthesis of nanodispersed $L_{a F}: T^{3+}$.} Synthesis of nanodispersed luminophor $\mathrm{LaF}_{3}: \mathrm{Tb}^{3+}$, was carried out by coprecipitation of components from aqueous and alcoholic (methanol) solution $[15,16]$. As precursors were used: $\mathrm{La}\left(\mathrm{NO}_{3}\right)_{3} \times 6 \mathrm{H}_{2} \mathrm{O}, \mathrm{TbCl}_{3}, \mathrm{NH}_{4} \mathrm{~F}$. All reagents have qualification "chemically pure". Distilled water and methanol were used as solvent. Used for synthesis: $18.473 \mathrm{~g} \quad \mathrm{La}\left(\mathrm{NO}_{3}\right)_{3} \times 6 \mathrm{H}_{2} \mathrm{O}$ (42.664 mmol), $5.708 \mathrm{~g} \mathrm{TbCl}_{3}(10.769 \mathrm{mmol})$, $4.773 \mathrm{~g} \mathrm{NH}_{4} \mathrm{~F}$ (127.992 mmol).

In order to obtain samples of $\mathrm{LaF}_{3}: \mathrm{Tb}^{3+}$, the following variants of synthesis were developed.

1. $\mathrm{La}^{3+}$ and $\mathrm{Tb}^{3+}$ salts in molar ratios of $4: 1$ were successively dissolved in a minimum volume of distilled water (or methanol). With constant stirring, the solution was added dropwise with the content of $\mathrm{F}^{-}$ions in the ratio La: $\mathrm{F}$ as 1: 3 . The reaction solution was stirred at room temperature for 2 hours. The product was centrifuged, washed three times with deionized water and dried at room temperature [21].

2. Components in the same ratios and sequences were introduced into the reactor and synthesized at $75^{\circ} \mathrm{C}$. An increase in temperature in this case leads to a relatively small increase in the size of the primary particles $(\sim 10-15 \%)$, a decrease in the degree of aggregation and the formation of a more ordered crystal structure [21-23].

3. The $\mathrm{LaF}_{3}: \mathrm{Tb}^{3+}$ nanoparticles obtained in the coprecipitation process were transferred to an autoclave with programmed heating / cooling at a rate of $1{ }^{\circ} \mathrm{C} / \mathrm{min}$ and kept at $150{ }^{\circ} \mathrm{C}$ for 24 hours. The obtained products were separated and after washing were dried at $60{ }^{\circ} \mathrm{C}$. Treatment with elevated temperature and pressure leads to the disappearance of small crystals, the evolution of the shape of the base of the crystals to a hexagonal and the formation of a porous surface of the samples [24-27].

4. $\mathrm{NCs} \mathrm{Fe}_{3} \mathrm{O}_{4} / \mathrm{LaF}_{3}: \mathrm{Tb}^{3+}[29]$ in this work was synthesized as follows: first to washed with distilled water to $\mathrm{pH}=7$ source freshly synthesized magnetite [14] a solution of salts of $\mathrm{La}^{3+}$ and $\mathrm{Tb}^{3+}$ was added in the ratio of active hydroxyl groups on its surface to the number of $\mathrm{La}^{3+}$ ions as 1: 1 (according to DTA, the concentration of hydroxyl groups on the surface of $\mathrm{Fe}_{3} \mathrm{O}_{4}$ was $2.2 \mathrm{mmol} / \mathrm{g}$ ) and left for 24 hours for adsorption saturation of the surface. Then the salt solution was drained, the $\mathrm{Fe}_{3} \mathrm{O}_{4}$ particles with adsorbed $\mathrm{La}^{3+}$ and $\mathrm{Tb}^{3+}$ were washed three times into $50 \mathrm{ml}$ of deionized water. After that, with constant stirring, the solution was added dropwise with the content of $\mathrm{F}^{-}$ions in the ratio $\mathrm{La}: \mathrm{F}$ as 1: 3 (it is assumed that all ions $\mathrm{La}^{3+}$ and $\mathrm{Tb}^{3+}$ are 
adsorbed on the surface of $\mathrm{Fe}_{3} \mathrm{O}_{4}$ ). The obtained $\mathrm{NCsFe}_{3} \mathrm{O}_{4} / \mathrm{LaF}_{3}: \mathrm{Tb}^{3+}$ was washed with distilled water and dried at $60{ }^{\circ} \mathrm{C}$. Note that the chosen method of synthesis of $\mathrm{NCsFe}_{3} \mathrm{O}_{4} / \mathrm{LaF}_{3}: \mathrm{Tb}^{3+}$ promotes the formation of their structure by the type of nucleus $\left(\mathrm{Fe}_{3} \mathrm{O}_{4}\right)-$ shell $\left(\mathrm{LaF}_{3}: \mathrm{Tb}^{3+}\right)$.

Synthesis of nanosized $\mathrm{Fe}_{3} \mathrm{O}_{4}$. Nanodisperse magnetite in the single-domain state was synthesized by the Elmore reaction [14].

Synthesis of sol-gel bioglass (BG 60S). The synthesis of bioglass (BG 60S) was carried out by the sol-gel method [6]. 60S glass has a composition (mol \%) of $60 \% \mathrm{SiO}_{2}, 36 \% \mathrm{CaO}$, $4 \% \mathrm{P}_{2} \mathrm{O}_{5}$. The synthesis was carried out by sol-gel method using: tetraethyl orthosilicate (TEOS) $\left(\mathrm{C}_{2} \mathrm{H}_{5} \mathrm{O}\right)_{4} \mathrm{Si}$, triethyl phosphate (TEF) $\left(\mathrm{C}_{2} \mathrm{H}_{5} \mathrm{O}\right)_{3} \mathrm{PO}$, ethanol $\mathrm{C}_{2} \mathrm{H}_{5} \mathrm{OH}$, calcium nitrate tetrahydrate $\left(\mathrm{Ca}\left(\mathrm{NO}_{3}\right)_{2} \times 4 \mathrm{H} 2 \mathrm{O}\right), 59 \%$ solution of nitric acid $\left(\mathrm{HNO}_{3}\right)$. Mass ratios of precursors for the synthesis of $60 \mathrm{~S}$ glass were: $\left(\mathrm{C}_{2} \mathrm{H}_{5} \mathrm{O}\right)_{4} \mathrm{Si}:\left(\mathrm{C}_{2} \mathrm{H}_{5} \mathrm{O}\right)_{3} \mathrm{PO}:\left(\mathrm{Ca}\left(\mathrm{NO}_{3}\right)_{2} \cdot 4 \mathrm{H}_{2} \mathrm{O}\right)$ : $\mathrm{H}_{2} \mathrm{O}: \mathrm{C}_{2} \mathrm{H}_{5} \mathrm{OH}=8.59: 1: 5.85: 9: 3$.

XRD analysis of samples. Structural studies the obtained samples were performed by powder $\mathrm{X}$-ray diffraction method (XRD) using a DRONUM1 diffractometer ("Burevestnik", Russia) with Fe filtered $\mathrm{Co}_{\alpha}$ radiation, focusing on BraggBrentano, in $2 \theta$ range of $10-80^{\circ}$. The size of the crystallites was determined by the width of the corresponding most intense line according to the Scherer equation.

Magnetic properties. Hysteresis loops of the magnetic moment of the samples were measured using a laboratory vibrating magnetometer of the Foner type at room temperature. Demagnetized NP were distributed in paraffin matrix with a volume concentration $\sim 0.05$ to prevent interaction. For comparison, we used materials with a known value of the specific saturation magnetization $\left(\sigma_{\mathrm{s}}\right)$ : a tested sample of nickel and magnetite NP (98 \%) manufactured by Nanostructured \& Amorphous Materials Inc., USA. In relation to the reference sample, the measurement error $\sigma_{\mathrm{s}}$ did not exceed $2.5 \%$.

DTGA study of samples. Study of samples by differential thermal analysis (DTGA) was performed using a Q-1500D (IOM Hungary).

TEM study of samples. To study the morphology and size of NPs used their dispersions in aqueous-ethanol solution (Transmission Electron Microscope JEM-2100F, Japan).
Study of luminescence of samples. Excitation of the luminescence of the samples was carried out by radiation of the lamp DRSH-500, passed through an UV filter MidOptBP324.

\section{RESULTS AND DISCUSSION}

The results study of X-ray diffraction are shown in Fig. $1 a, b, c$. It can be seen that the diffraction patterns of $\mathrm{LaF}_{3}: \mathrm{Tb}^{3+}$ samples synthesized (Fig. $1 a, b$ ) in water and methanol do not differ fundamentally. Under the conditions of the experiments, the most perfect crystals were formed during crystallization in an autoclave. Their average size was $\sim 15 \mathrm{~nm}$. Lanthanum (III) fluoride forms colorless crystals of hexagonal syngony, spatial group $\mathrm{P} 3 \mathrm{c} 1$, unit cell parameters $a=0.7186 \mathrm{~nm}, c=0.7352 \mathrm{~nm}, Z=6$; insoluble in water; forms crystal hydrates of $\mathrm{LaF}_{3} \times 0.5 \mathrm{H}_{2} \mathrm{O}$ composition.

Fig. 2 shows TEM images of $\mathrm{LaF}_{3}: \mathrm{Tb}^{3+}$ nanocrystals synthesized in an aqueous medium. It is seen that the length of the crystals exceeds the width by 3-4 times. Crystals are prone to aggregation and the formation of chain structures. Note that the advantage of the method of obtaining a nanoscintillators in aqueous and in alcoholic environment is the capability to combine in a single process the synthesis of nanocomposite magnetic fluids and bioactive ceramic materials based on phosphates and silicates, with a content of $\mathrm{LaF}_{3}: \mathrm{Tb}^{3+}$.

The luminescence spectrum of a sample of nanodispersed $\mathrm{LaF}_{3}: \mathrm{Tb}^{3+}$, when diluted in water at the concentration of $0.5 \mathrm{mg} / \mathrm{ml}$ and when excited by ultraviolet radiation (Fig. 3 curve 1), shows bands characteristic of the structure of $\mathrm{LaF}_{3}: \mathrm{Tb}^{3+}$ $[15,16]$. For comparison, the luminescence spectrum of an undoped $\mathrm{LaF}_{3}$ sample under the same conditions is given (curve 2).

The synthesized $\mathrm{NPs} \mathrm{Fe}_{3} \mathrm{O}_{4}$ in the original ensemble were characterized by sizes $3-23 \mathrm{~nm}$ and a single-domain state. An ensemble of NPs with an average size of $11 \mathrm{~nm}$ was used in this work. The specific surface area of the synthesized magnetite was $S_{s p}=105 \mathrm{~m}^{2} / \mathrm{g}$. Magnetite was characterized by a coercive force $H_{\mathrm{c}}=55.0 \mathrm{E}$, specific saturation magnetization $\sigma_{s}=56.2 \mathrm{Gs} \cdot \mathrm{cm}^{3} / \mathrm{g}$, relative residual magnetization $M_{r} / M_{s}=0.2$ and can be used as a magnetically sensitive carrier for targeted delivery of drugs and biologically active compounds.

For the TEM image of the ensemble of particles of $\mathrm{NCsFe}_{3} \mathrm{O}_{4} / \mathrm{LaF}_{3}: \mathrm{Tb}^{3+}$ is characterized 
by a fundamental difference in the structure of particles from the structure of nanocrystals $\mathrm{LaF}_{3}: \mathrm{Tb}^{3+}$ (Fig. $2 a$ ) - close to spherical, which is characteristic of NCs core-shell type (Fig. 4). X-ray diffraction patterns (Fig. 5) confirm the

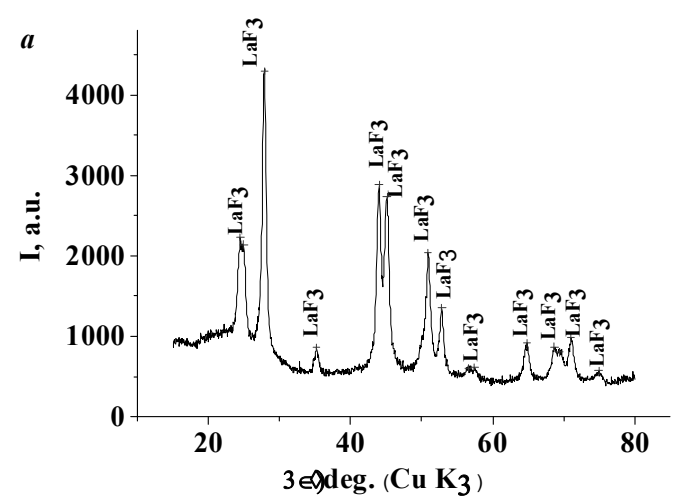

conclusion about the formation of the structure of the core-shell type $\mathrm{NCsFe}_{3} \mathrm{O}_{4} / \mathrm{LaF}_{3}: \mathrm{Tb}^{3+}$. Note that the conditions for the synthesis of NCs did not significantly change the magnetic properties of their nuclei - single-domain $\mathrm{NPs} \mathrm{Fe}_{3} \mathrm{O}_{4}$.
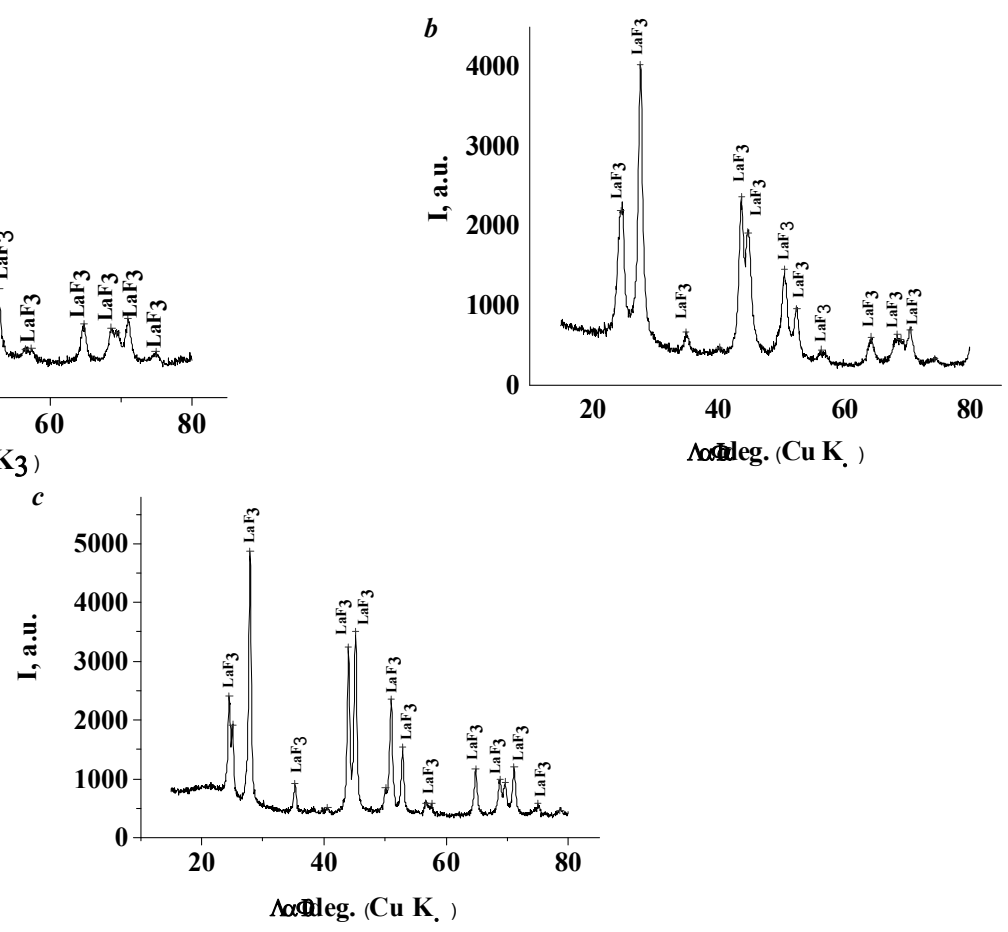

Fig. 1. XRD patterns of $\mathrm{LaF}_{3}: \mathrm{Tb}_{3}$ samples synthesized in water $(a)$, methanol $(b)$ and in an autoclave $(c)$
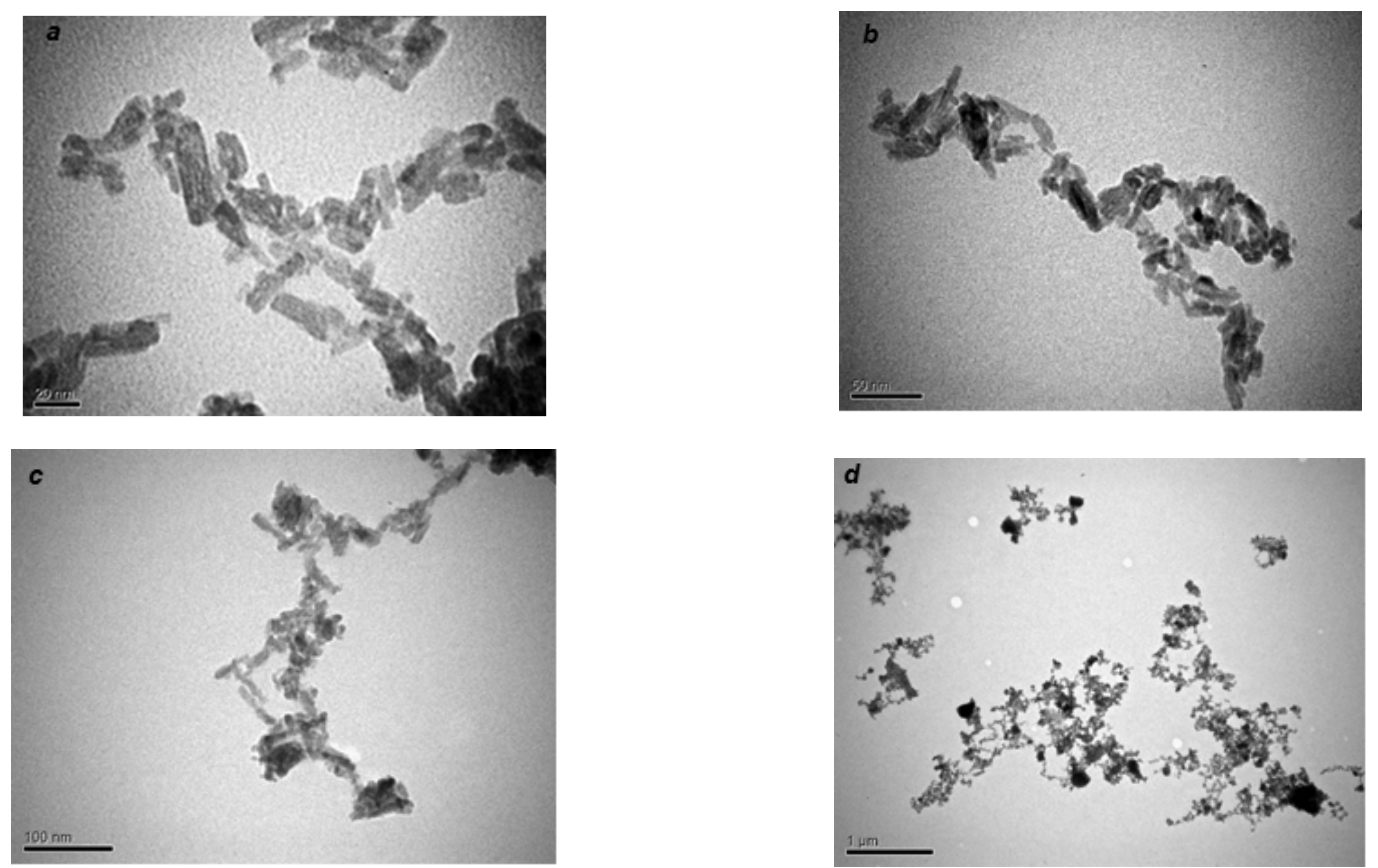

Fig. 2. TEM images of $\mathrm{LaF}_{3}: \mathrm{Tb}^{3+}$ nanocrystals: $a$ - scale bar $20 \mathrm{~nm} ; b$ - scale bar $50 \mathrm{~nm} ; c-$ scale bar $100 \mathrm{~nm}$; $d$ - scale bar $1000 \mathrm{~nm}$ 
The luminescence spectrum of NCs $\mathrm{Fe}_{3} \mathrm{O}_{4} / \mathrm{LaF}_{3}: \mathrm{Tb}^{3+}$ (Fig. 6) differs significantly from the spectrum of samples of nanodispersed $\mathrm{LaF}_{3}: \mathrm{Tb}^{3+}$ (Fig. 3, curve 1) both in intensity and in the structure of the bands. These spectral differences may be due to differences in structure, features of the nanocrystalline structure, the content of the $\mathrm{LaF}_{3}: \mathrm{Tb}^{3+}$ scintillator and $\mathrm{Tb}^{3+}$ ions in it (Fig. 3, curve 1) in shells of NCs $\mathrm{Fe}_{3} \mathrm{O}_{4} / \mathrm{LaF}_{3}: \mathrm{Tb}^{3+}$ (Fig. 6, curve 1).

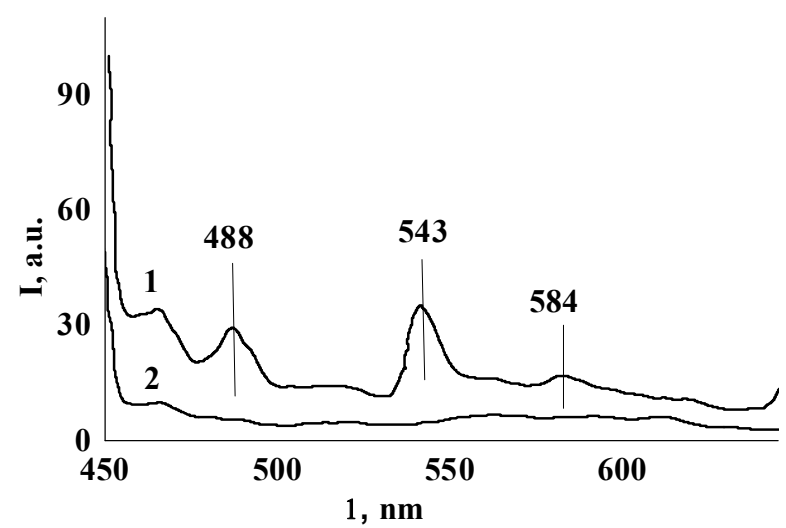

Fig. 3. Luminescence spectrum of nanodispersed samples $\mathrm{LaF}_{3}: \mathrm{Tb}^{3+}(1) \mathrm{Ta} \mathrm{LaF}_{3}$ (2) dilution $0.5 \mathrm{mg} / \mathrm{ml}$

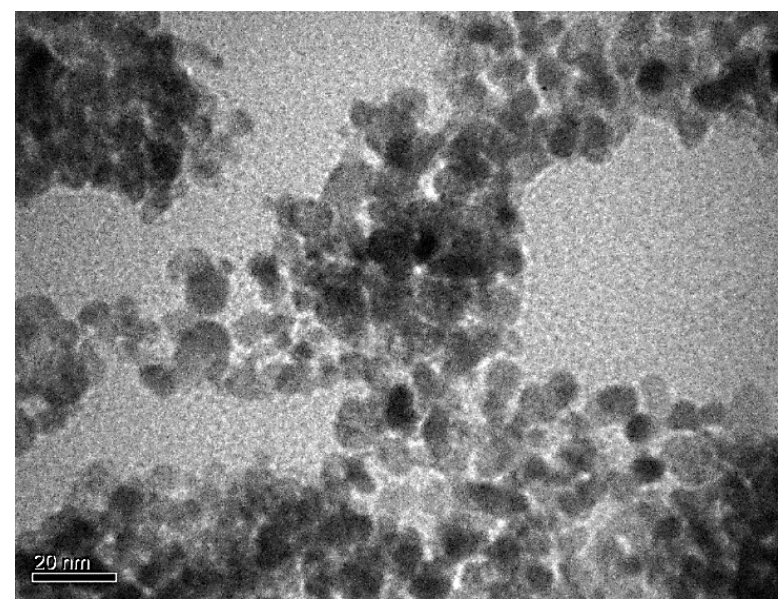

Fig. 4. TEM images of $\mathrm{NCs} \mathrm{Fe}_{3} \mathrm{O}_{4} / \mathrm{LaF}_{3}: \mathrm{Tb}^{3+}$; scale bar $20 \mathrm{~nm}$

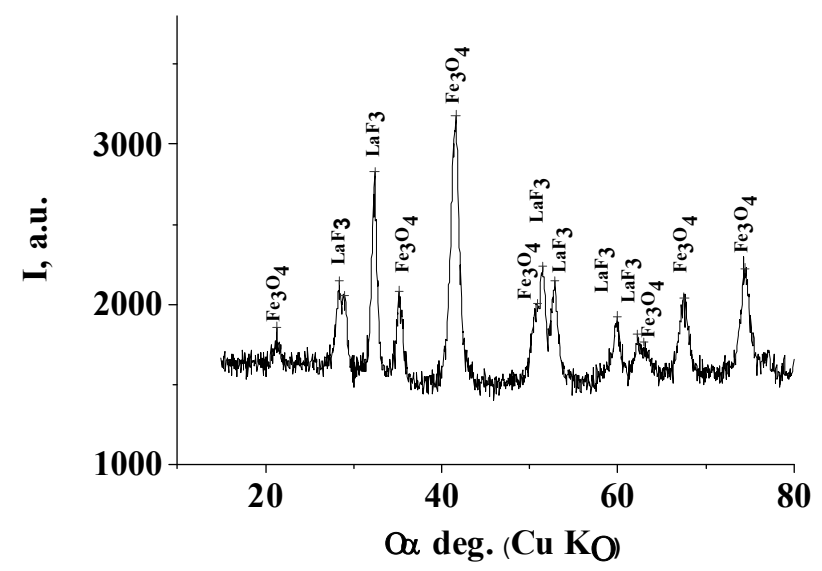

Fig. 5. XRD patterns of $\mathrm{NCs} \mathrm{Fe}_{3} \mathrm{O}_{4} / \mathrm{LaF}_{3}: \mathrm{Tb}^{3+}$ 


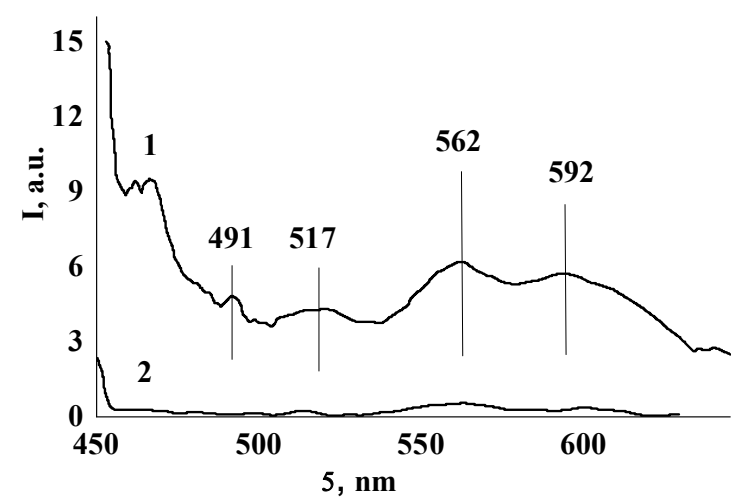

Fig. 6. Luminescence spectrum of nanodispersed samples $\mathrm{Fe}_{3} \mathrm{O}_{4} / \mathrm{LaF}_{3}: \mathrm{Tb}^{3+}(1)$ and $\mathrm{Fe}_{3} \mathrm{O}_{4} / \mathrm{LaF}_{3}(2)$ dilution $0.1 \mathrm{mg} / \mathrm{ml}$

In conclusion, the composites of dispersed bioglass $60 \mathrm{~S}$ and nanodispersed crystalline $\mathrm{LaF}_{3}: \mathrm{Tb}^{3+}$ in the dry state, and in distilled water, showed the presence of luminescence when excited by UV radiation, which indicates the possibility of their use in photodynamic therapy of bone cancer.

These data indicate the achievement of the goal of this work. In the future, the optimization of the luminescent properties of the original nanodisperse luminophors, their compositions with bioactive glass, luminescent shells in the composition of magnetically sensitive $\mathrm{NC}$, as well as the technology of manufacturing these structures. We hope that this will significantly improve their performance, create the prospect of use in photodynamic therapy and optopharmacology as sources of luminescent radiation and drug carriers, both individually and as part of various types of nanocomposites.

\section{CONCLUSIONS}

Nanodispersed luminophors of $\mathrm{LaF}_{3}: \mathrm{Tb}^{3+}$ type were synthesized, promising for use as a source of luminescent radiation both in individual application and as a part of nanocomposites of different types; their structural properties and luminescence spectra during UV excitation were studied. Diffractograms of the samples of $\mathrm{LaF}_{3}$ : $\mathrm{Tb}^{3+}$ synthesized in water and methanol are not fundamentally different. Under the experimental conditions, the most perfect crystals of hexagonal syngony were formed during crystallization in an autoclave. Their average size was $\sim 15 \mathrm{~nm}$. The length of TEM images of crystals exceeds the width by 3-4 times. Crystals are prone to aggregation and the formation of chain structures. The UV luminescence spectrum of the synthesized nanodisperse samples upon excitation by ultraviolet radiation is characteristic of $\mathrm{LaF}_{3}: \mathrm{Tb}^{3+}$.

Ensembles of $\mathrm{Fe}_{3} \mathrm{O}_{4} / \mathrm{LaF}_{3}: \mathrm{Tb}^{3+} \mathrm{NC}$ particles with a core-shell type structure were synthesized. The conditions for the synthesis of NCs did not significantly change the magnetic properties of their nuclei, single-domain $\mathrm{Fe}_{3} \mathrm{O}_{4}$ NP. The luminescence spectrum of $\mathrm{Fe}_{3} \mathrm{O}_{4} / \mathrm{LaF}_{3}: \mathrm{Tb}^{3+} \mathrm{NCs}$ differs significantly from those of the samples of nanodispersed $\mathrm{LaF}_{3}: \mathrm{Tb}^{3+}$ both in intensity and in the structure of the bands. These spectral differences are probably due to differences in nanocrystalline structure, content of $\mathrm{Tb}^{3+}$ ions, etc. in samples of $\mathrm{LaF}_{3}: \mathrm{Tb}^{3+}$ nanocrystals and shells of $\mathrm{Fe}_{3} \mathrm{O}_{4} / \mathrm{LaF}_{3}: \mathrm{Tb}^{3+}$ nanocomposites.

The composites of dispersed bioglass $60 \mathrm{~S}$ with nanodispersed crystalline $\mathrm{LaF}_{3}: \mathrm{Tb}^{3+}$ in the dry state, and in distilled water, showed the presence of luminescence when excited by UV radiation.

The results of the work indicate the prospects of the synthesized structures for further research under the conditions of excitation by highpermeability "soft" X-ray radiation for use in optopharmacology and photodynamic therapy of tumors in organs of cranial cavity and bone tissues. Optimization of properties of the original nanodispersed luminophors, their compositions with bioactive glass and magnetosensitive carriers $\mathrm{Fe}_{3} \mathrm{O}_{4}$ will allow us to improve significantly their performance characteristics. 


\title{
Синтез та властивості наноструктур на основі фториду лантану для фотодинамічної терапії пухлинних захворювань органів черепної порожнини та кісткових тканин
}

\author{
А.П. Кусяк, А.Л. Петрановська, С.П. Туранська, О.І. Оранська, Я.М. Шуба, Д.І. Кравчук, \\ Л.І. Кравчук, О.А. Бур'янов, В.С. Чорний, Ю.Л. Соболевський, В.А. Дубок, П.П. Горбик
}

\author{
Інститут хімії поверхні ім. О.О. Чуйка Наиіональної академії наук України \\ вул. Генерала Наумова, 17, Київ, 03164, Україна, phorbyk@ukr.net \\ Інститут фізіології ім. О.О. Богомольия Наиіональної академії наук України \\ вул. Академіка Богомольия, 4, Київ, 01601, Україна \\ Наиіональний медичний університет ім. О.О. Богомольия \\ бул. Тараса Шевченка, 13, Київ, 0160, Україна \\ Інститут проблем матеріалознавства ім. І.М. Францевича Наџіональної академії наук України \\ вул. Кржижанівського, б. 3, Київ, 03142, Україна
}

\begin{abstract}
Метою роботи є синтез наноструктур на основі фториду лантану, перспективних для застосування 6 фотодинамічній терапії пухлинних захворювань органів черепної порожнини та кісткових тканин; дослідження їхніх структурних властивостей і спектрів люмінесиенції. Синтез LaF : $_{3} b^{3+}$ здійснено співосадженням компонентів із водного та спиртового (метанол) розчину. Як прекурсори використано: $\mathrm{La}\left(\mathrm{NO}_{3}\right)_{3} \times 6 \mathrm{H}_{2} \mathrm{O}, \mathrm{TbCl}_{3}, \mathrm{NH}_{4} \mathrm{~F}$. Всі реактиви кваліфікації «хч». Як розчинник використано дистильовану воду, метанол. Синтез нанорозмірного магнетиту в однодоменному стані виконували методом Елмора. Синтезовані нанодисперсні зразки були охарактеризовані методами рентгенівської дифракиії, диференціального термогравіметричного аналізу, просвічуючої електронної мікроскопії. Вивчалися також магнітні властивості $i$ спектри УФ-люмінесценції. Виявлено, що дифрактограми зразків LaF $: \mathrm{Tb}^{3+}$, синтезованих у середовищі води і метанолу, принципово не різняться. В умовах експериментів найбільщ досконалі кристали гексагональної сингонії утворювались при кристалізації в автоклаві. Їхній середній розмір становив 15 нм. Довжина ПЕМ-зображень кристалів $\mathrm{LaF}_{3}: \mathrm{Tb}^{3+}$ перевищує ширину в 3-4 рази. Кристали схильні до агрегаиії та утворення ланцюжкових структур. Спектр УФ-люмінесиенції синтезованих нанодисперсних зразків в середовищі води в концентрації 0.5 мг/мл та збудженні ультрафіолетовим випромінюванням $\epsilon$ характерним для структури $\mathrm{LaF}_{3}: \mathrm{Tb}^{3+}$. Синтезовано ансамблі частинок HК $\mathrm{Fe}_{3} \mathrm{O}_{4} / \mathrm{LaF}_{3}: \mathrm{Tb}^{3+}$. Методами просвічуючої електронної мікроскопії встановлено, щэо форма частинок НК $i$

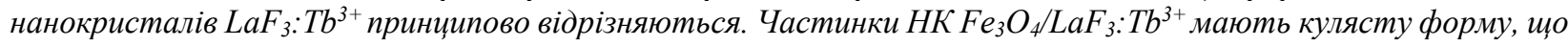
характерно структурам типу ядро-оболонка. Рентгенівські дифрактограми НК підтверджують цей висновок. Умови синтезу НК істотно не змінювали магнітні властивості їхніх ядер-однодоменних $\mathrm{HY} \mathrm{Fe}_{3} \mathrm{O}_{4}$. Спектр люмінесиениії $\mathrm{HK} \mathrm{Fe}_{3} \mathrm{O}_{4} / \mathrm{LaF}_{3}: \mathrm{Tb}^{3+}$ істотно відрізняється від спектра зразків нанодисперсних $\mathrm{LaF}_{3}: \mathrm{Tb}^{3+}$ як за інтенсивністю, так $i$ за структурою смуг. Вказані спектральні відмінності можуть бути обумовлені відмінностями будови, особливостями нанокристалічної структури, вмістом сиинтилятора $\mathrm{LaF}_{3}: \mathrm{Tb}^{3+}$ та іонів $\mathrm{Tb}^{3+}$ в зразках нанокристалів $\mathrm{LaF}_{3}: \mathrm{Tb}^{3+}$ та оболонках нанокомпозитів $\mathrm{Fe}_{3} \mathrm{O}_{4} / \mathrm{LaF}_{3}: \mathrm{Tb}^{3+}$. Композити диспергованого біоскла 60S з нанодисперсним кристалічним LaF $F_{3} T^{3+}$ в сухому стані та середовищі дистильованої води демонстрували наявність люмінесиенції при збудженні УФ-випромінюванням. Результати роботи свідчать про перспективність синтезованих структур для подальших досліджень в умовах збудження високопроникним «м'яким» рентгенівським випромінюванням з метою їхнього використання в оптофармакології та фотодинамічній терапії пухлинних захворювань органів черепноі порожнини та кісткових тканин. Оптимізаиія властивостей вихідних нанодисперсних люмінофорів, їхніх композицій з біоактивним склом та магніточутливими носіями $\mathrm{Fe}_{3} \mathrm{O}_{4}$ дозволить істотно покращити експлуатаційні характеристики.
\end{abstract}

Ключові слова: нанодисперсні люмінофори, фторид лантану, нанокомпозити, магнетит, біоскло

\section{REFERENCES}

1. Roco M.C., Williams R.S., Alivisatos P. Vision for Nanotechnology R\&D in the Next Decade. (Dordrecht: Kluwer Acad. Publ., 2002).

2. Shpak A.P., Gorbyk P.P. Nanomaterials and Supramolecular Structures: Physics, Chemistry, and Applications. (Nederlands: Springer, 2009). 
3. Gorbyk P.P., Lerman L.B., Petranovska A.L., Turanska S.P., Pylypchuk I.V. Magnetosensitive Nanocomposites with Hierarchical Nanoarchitecture as Biomedical Nanorobots: Synthesis, Properties, and Application. In: Fabrication and Self-Assembly of Nanobiomaterials, Applications of Nanobiomaterials. (Elsevier, 2016).

4. Abramov M.V., Kusyak A.P., Kaminskiy O.M., Turanska S.P., Petranovska A.L., Kusyak N.V., Gorbyk P.P. Magnetosensitive nanocomposites based on cisplatin and doxorubicin for application in oncology. In: Horizons in World Physics. 2017. 293: 1.

5. Abramov M.V., Petranovska A.L., Kusyak N.V., Kusyak A.P., Korniichuk N.M., Turanska S.P., Gorbyk P.P., Luk'yanova N.Yu., Chekhun V.F. Synthesis and properties of magnetosensitive nanocomposites and ferrofluids based on magnetite, gemcitabine and HER2 antibody. Funct. Mater. 2020. 27(2): 283.

6. Kusyak A.P., Petranovska A.L., Dubok V.A., Chornyi V.S., Bur'yanov O.A., Korniichuk N.M., Gorbyk P.P. Adsorption immobilization of chemotherape utic drugcis platin on the surface of sol-gel bioglass 60S. Funct. Mater. 2021. 28(1): 97.

7. Hench L.L., Fielder E. Biological Gel-Glasses. In: Sol-Gel Technologies for Glass Producers and Users. (Springer Science, Business Media, 2004).

8. Dutra C.E.A., Pereira M.M., Serakides R., Rezende C.M.F. In vivo evaluation of bioactive glass foams associated with platelet-rich plasma in bone defects. J. Tissue Eng. Regener. Med. 2008. 2(4): 221.

9. Buryanov O.A., Chornyi V.S., Protsenko V.V., Shapovalov V.S., Kusyak V.A. Analysis of replacement of bone defects by calcium phosphate biomaterials in bone diseases. Litopys Travmat. Ortoped. 2018. 1-2: 37. [in Ukrainian].

10. Kusyak A.P., Petranovska A.L., Shuba Y.M., Kravchuk D.I., Kravchuk L.I., Buryanov O.A., Chornyi V.S., Sobolevskyi Y.L., Gorbyk P.P. Synthesis and properties of nanodisperse luminophores for photodynamic and optopharmacologic therapies of tumors of cranial cavity and bone tissue. In: Chemistry, Physics and Technology of Surface. Nanostructures and Nanomaterials in Medicine: Challenges, Tasks and Perspectives. Proc. Ukr. Int. Conf., Workshop (Kyiv, 2021). P. 125.

11. Medvedev I.B., Belikova Ye.I., Syamichev M.P. Photodynamic therapy in ophthalmology. (Moscow, 2006). [in Russian].

12. Helfond M.L. Photodynamic therapy in oncology. Pract. Oncol. 2007. 8(4): 204. [in Russian].

13. Lytvynenko B.V., Korovin S.I., Litus O.I., Bashtan V.P., Lytvynenko V.Ye. Photodynamic therapy is a modern effective method of treating basal cell skin cancer. Clinical Surgery. 2016. 6: 71. [in Ukrainian].

14. Gorobets' S.V., Gorobets' O.Yu., Gorbyk P.P., Uvarova I.V. Functional bio- and nanomaterials of medical destination. (Kyiv: Kondor, 2018). [in Ukrainian].

15. Min-Hua C., Yi-Jhen J., Sheng-Kai W., Yo-Shen C., Nobutaka H., Feng-Huei L. Non-invasive photodynamic therapy in brain cancer by use of $\mathrm{Tb}^{3+}$-doped $\mathrm{LaF}_{3}$ nanoparticles in combination with photosensitizer through X-ray irradiation: a proof-of-concept study. Nanoscale Res. Let. 2017. 12: 62.

16. Liu Y., Chen W., Wang S., Joly A.G., Westcott S., Woo B.K. X-ray luminescence of $\mathrm{LaF}_{3}: \mathrm{Tb}^{3+} \mathrm{and} \mathrm{LaF}_{3}: \mathrm{Ce}^{3+}$, $\mathrm{Tb}^{3+}$ water-soluble nanoparticles. J. Appl. Phys. 2008. 103(6): 063105.

17. Hsiu-Wen C., Chien-Hao H., Chien-Hsin Y., Tzong-Liu W. Synthesis, optical properties, and sensing applications of $\mathrm{LaF}_{3}: \mathrm{Yb}^{3+} / \mathrm{Er}^{3+} / \mathrm{Ho}^{3+} / \mathrm{Tm}^{3+}$ upconversion nanoparticles. Nanomaterials. 2020. 10(12): 2477.

18. Gorbyk P.P. Medico-biological nanocomposites with functions of nanorobots: state of research, development and prospects for practical implementation. Him. Fiz. Tehnol. Poverhni. 2020. 11(1): 128. [in Ukrainian].

19. Dubok V.A., Protsenko V.V., Shynkaruk A.V., Atamanenko O.N. A new generation of bioactive ceramics special features of properties and clinical results. Orthopedics, Traumatology and Prosthetics. 2008. 3: 91. [in Russian].

20. Buryanov A.A., Chornyi V.S., Dedukh N.V., Dubok V.A., Protsenko V.V., Omelchenko T.N., Vakulich M.V., Lyanskorunskiy V.N., Shapovalov V.S., Abudeikh U. Peculiarities of regenerative reactions in filling bone defects with bioglass in combination with autologous plasma enriched with platelets. Trauma. 2019. 20(6): 56. [in Russian].

21. Mangaiyarkarasi R., Chinnathambi S., Karthikeyan S., Aruna P., Ganesan S. Paclitaxel conjugated $\mathrm{Fe}_{3} \mathrm{O}_{4} @ \mathrm{LaF}_{3}: \mathrm{Ce}^{3+}, \mathrm{Tb}^{3+}$ nanoparticles as bifunctional targeting carriers for cancer theranostics application. J. Magn. Magn. Mater. 2016. 399: 207.

22. Zhang F., Braun G.B., Pallaoro A., Zhang Y., Shi Y., Cui D., Moskovits M., Zhao D., Stucky G.D. Mesoporous multifunctional upconversion luminescent and magnetic "nanorattle" materials for targeted chemotherapy. Nano Lett. 2011. 12(1): 61.

23. DiMaio J., Kokuoz B., James T.L., Harkey T., Monofsky D., Ballato J. Photoluminescent characterization of atomic diffusion in core-shell nanoparticles. Opt. Express. 2008. 16(16): 11769.

24. Jing K., Guo X., Diao X., Wu Q., Jiang Y., Sun Y., Zhu Y. Synthesis and characterization of dipicolinate sensitized $\mathrm{LaF}_{3}: \mathrm{Tb}^{3+}$ nanoparticles and their interaction with bovine serum albumin. J. Lumin. 2015. $157: 184$. 
25. Patro L.N., Kamala Bharathi K., Ravi Chandra Raju N. Microstructural and ionic transport studies of hydrothermally synthesized lanthanum fluoride nanoparticles. AIP Adv. 2014. 4(12): 127139.

26. Tang Y., Hu J., Elmenoufy A.H., Yang X. Highly efficient FRET system capable of deep photodynamic therapy established on X-ray excited mesoporous $\mathrm{LaF}_{3}: \mathrm{Tb}$ scintillating nanoparticles. ACS Appl. Mater. Interfaces. 2015. 7(22): 12261.

27. Kasturi S., Marikumar R., Vaidyanathan S. Trivalent rare-earth activated hexagonal lanthanum fluoride $\left(\mathrm{LaF}_{3}\right.$ $: \mathrm{RE}^{3+}$, where $\mathrm{RE}=\mathrm{Tb}, \mathrm{Sm}$, Dy and Tm) nanocrystals: synthesis and optical properties. J. Lumin. 2018. 33(5): 897. 